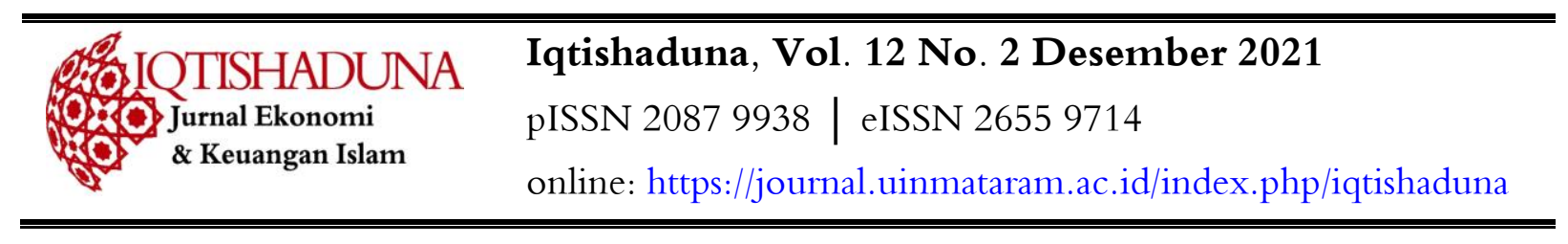

\title{
Anomali Murabahah di Perbankan Syari'ah (Analisis Rekayasa Pengembangan dan Peningkatan Kualitas Produk)
}

\author{
Gatot Suhirman \\ Universitas Islam Negeri Mataram \\ gatotsuhirman@,uinmataram.ac.id
}

\begin{abstract}
Abstrak
Keberadaan pembiayaan Murabahah di perbankan syari'ah bagaikan pisau bermata dua. Satu sisi, produk murabahah selalu menjadi produk unggulan dan menjadi primadona bagi bank syariah. Di sisi lain, salah satu produk utama bank syari'ah ini senantiasa mendapat kritik tajam dari berbagai elemen. Bagi sebagian kalangan, penerapan pembiayaan Murabahah secara dominan, akan semakin membuktikan bawha bank syari'ah tidak jauh berbeda dengan bank konvensional yang menerapkan sistem bunga. Produk berbasis bagi hasil seharusnya menjadi produk utama dan diutamakan untuk menghantam institusi riba. Akibatnya, Murabahah di bank syari'ah dianggap transaksi mirip bunga pada bank konvensional. Namun demikian, berdasarkan analisis metodologi pengembangan dan peningkatan (kualitas) produk dari perspektif syari'ah, "rekayasa produk" untuk menyesuaikan diri supaya tidak bertentangan dengan syari'at Islam dapat dibenarkan.
\end{abstract}

Kata Kunci: murabahah, bank syariah, rekayasa produk

\section{PENDAHULUAN}

Pada dasarnya, setiap muslim dari kalangan fuqaha, imam mazhab hingga ummat yang awam sekalipun meyakini bahwa riba merupakan sesuatu yang diharamkan secara mutlak dalam ekonomi Islam (muamalat). Akan tetapi, yang senantiasa menjadi perdebatan di kalangan ulama adalah bagaimana menafsirkan riba seiring dengan perkembangan dan kemajuan yang dicapai umat dalam lapangan muamalat yang sudah barang tentu berbeda dan lebih kompleks dengan praktik muamalat yang berkembang ketika wahyu tentang pengharaman riba diturunkan dahulu. Al-Qur'an memang secara tegas menyatakan bahwa haramnya riba merupakan persoalan yang final, absolut dan mustahil untuk diubah. Namun, harus diakui pula bahwa tidak tersedia penjelasan yang mendetail dalam praktik Rasulullah SAW. Tidak tersedianya penjelasan mendetail dalam praktik Rasulullah saw. itu dapat dinisbatkan kepada dua alasan: pertama, bahwa ayat yang berkenaan dengan riba diturunkan pada akhir kehidupan Rasulullah saw., dan karenanya tidak banyak contoh kasus para sahabat bertanya tentang istilah riba kepada Rasulullah dan kemudian dijelaskan dengan rinci. Alasan kedua, dan yang lebih kuat, adalah riba merupakan istilah yang 
telah matang dan masyhur pada saat pewahyuannya dan karena itu Rasulullah tidak merasa adanya kebutuhan akan penjelasan atau elaborasi lebih lanjut. ${ }^{1}$ Dalam konteks demikian, umat Islam menemui kesulitan dalam hal mengidentifikasi dan menentukan ke-syariah-an suatu praktik ekonomi yang senantiasa selalu mengalami perkembangan dan kemajuan dari waktu ke waktu. Tak dapat dipungkiri, dalam situasi seperti itu seringkali terjadi perbedaan pendapat di kalangan para ahli (ulama) dalam menilai suatu praktek muamalat (ekonomi Islam) teridentifikasi sebagai riba atau bukan.

Perdebatan tentang bunga (bank) adalah salah satu contoh kongkret dari persoalan yang paling banyak mendapatkan perhatian dalam diskursus seputar riba modern. Polemik dan perbedaan pendapat tentang bunga, khususnya bunga dalam institusi bank (konvensional) tak kunjung usai dari dulu, sekarang, bahkan mungkin untuk masa yang akan datang. Adanya kecenderungan polemik tersebut dilatarbelakangi oleh perbedaan pendekatan dan metode dalam memahami nash yang sama. Dalam hal ini, umat Islam terpecah menjadi dua golongan besar, Mazhab Tekstualis dan Mazhab Kontekstualis-Modernis, sedangkan sisanya memberi status bunga (bank) tidak jelas atau syubhat. ${ }^{2}$ Mazhab Tekstualis berprinsip semua jenis tambahan dalam transaksi pinjaman adalah haram, karena hakikat tambahan sama dengan riba. Sedangkan Mazhab Kontekstualis-Modernis, dengan pendekatan yang lebih membumi, tidak serta merta mengharamkan setiap bentuk tambahan (ziyadah). Golongan pertama lebih menitikberatkan pada aspek legal-formal larangan riba dalam mendiskusikan bunga bank, sedangkan golongan kedua melihat dari sudut pandang moralitas keadilan terhadap larangan tersebut. Menurut mazhab ini, yang menjadi persoalan bukan pada sedikit atau banyaknya tambahan -meskipun tetap ada tambahan-, tetapi terletak pada ada atau tidak adanya eksploitasi (zulm) sebagai 'illat hukumnya. ${ }^{3}$

Teori perbankan Islam, yang telah mulai berkembang sejak dekade 50-an, meneguhkan bahwa perbankan Islam adalah perbankan bebas bunga yang didasarkan pada konsep "bagi hasil" atau lebih dikenal dengan "profit and loss sharing". Para teoretisi perbankan dan fuqaha muslim yang menyumbangkan teori ini menafsirkan riba sebagai "bunga" (interest) dan "keuntungan yang telah ditentukan sebelumnya atas modal", khususnya modal uang. Dengan menafsirkan riba sebagai bunga, para teoretisi perbankan Islam menganut konsep awal bahwa setiap keuntungan yang ditambahkan atas pinjaman bagi pemberi pinjaman adalah riba. Berdasarkan pandangan ini,

\footnotetext{
1 Zamir Iqbal dan Abbas Mirakhor, Pengantar Keuangan Islam: Teori dan Praktek, A.K. Anwar (Penerj.), cet. I, (Jakarta: Kencana, 2008), h.70.

2 Muslihun, "Argumen-argumen Baru Pro-Kontra Bunga Bank", dalam Istinbath, No. 2, Vol. 1 Januari-Juni 2004, h. 119-120. Lihat juga, Gatot Suhirman, "Bunga dan Riba dalam Transaksi menurut Syari'ah:Sebuah Ikhtiar Mengurai Akar Perbedaan Pendapat", dalam Alamah: Jurnal Pembaruan Pemikiran Islam, Vol. VI, Januari-Desember 2008, h. 33-48.

3 Ibid.
} 
setiap penambahan (nominal atau riil) dalam suatu pinjaman yang diberikan kepada kreditur adalah riba. ${ }^{4}$ Akan tetapi, tidak hanya dalam transaksi pinjam-meminjam, dalam transaksi jual-beli pun, menurut teoretisi modern, kenaikan harga karena waktu, khususnya pada jual-beli tunda, adalah riba. ${ }^{5}$

Jika pada awalnya, sebagaimana gambaran di atas, perdebatan yang terjadi berkisar seputar perbedaan pendapat mengenai apakah bunga termasuk riba atau bukan, maka pada perkembangan selanjutnya, yakni setelah bank Islam tumbuh pesat, perdebatan "panas" yang berkembang justru terjadi dalam hal menentukan apakah suatu produk perbankan bebas-bunga (produk islami) benar-benar telah bebas dari unsur bunga atau tidak. Dalam hal ini, salah satu praktek (red: produk) perbankan syariah yang paling banyak mendapatkan respon pro-kontra adalah produk pembiayaan Murabahah. Pada tataran ini, perbedaan pendapat mengerucut pada dua pandangan, yakni pertama, kelompok yang mengatakan bahwa transaksi Murabahah di perbankan Islam tidak ada bedanya dengan praktek bunga di perbankan konvensional, dan kedua, kelompok yang menyatakan bahwa transaksi Murabahah di perbankan Islam tidak sama dengan transaksi bunga seperti yang berlaku di perbankan konvensional. ${ }^{6}$

Oleh karena itu, dalam tulisan ini sendiri penulis akan memaparkan bagaimana produk pembiayaan Murabahah yang notabene merupakan produk andalan perbankan syariah ternyata tak luput dari "badai" kritik. Supaya lebih sistematis, pembahasan ini dimulai dari literasi praktik pembiayaan Murabahah di perbankan syariah yang kemudian dilanjutkan dengan berbagai tinjauan seputar Murabahah serta analisis dari para pemerhati bagaimana produk pembiayaan Murabahah dibela atau didukung.

\section{STUDI LITERATUR}

Secara praktis, pembiayaan yang diberikan bank Islam (syariah) kepada nasabahnya tidak hanya diselesaikan dengan cara Murabahah dan Musyarakah. Bank syariah dapat juga menjalankan pembiayaan Murabahah dengan menggunakan akad jual-beli. Pada akad jual-beli, bank syariah memperoleh pendapatan secara pasti. Hal ini sesuai dengan konsep dasar teori pertukaran. Dimana teori pertukaran sering disebut sebagai natural certainty contract, yaitu kontrak bisnis yang memberikan kepastian pembayaran, baik dari segi jumlah maupun waktu. Sementara itu, jual beli

\footnotetext{
4 Abdullah Saeed, Islamic Banking and Interest: A Study of Probibition of Riba and Its Contemporary Interpretation ( Leiden: E..J. Brill, 1996), h. 26.

${ }^{5}$ Syed H.A.R. Al-Kaff, Does Islam Assign any Value/Weight to time Factor in Economic and Financial Transactions?, (Karachi: Islamic Research Academy, 1986), h. 12.

${ }^{6}$ Syaparuddin, "Kritik-kritik Abdullah Saeed terhadap Praktik Pembiayaan Murababab\}", Tesis pada Pascasarjana UIN Sunan Kalijaga, Yogyakarta, 2007.
} 
dalam Islam merupakan bentuk muamalat dalam pengertiannya yang khusus. Asas yang fundamental dalam muamalat, di antaranya adalah asas tabadu al-manafi' dan al-taradin. Asas tabadu al-manafi' ini menyatakan bahwa segala bentuk kegiatan muamalat harus memberikan keuntungan dan manfaat bagi pihak-pihak yang terlibat. Asas ini merupakan kelanjutan dari prinsip at-ta'awun, sehingga asas ini bertujuan menciptakan kerjasama antar individu dan pihak-pihak dalam masyarakat dalam rangka saling memenuhi keperluannya masing-masing untuk kesejahteraan bersama. Sedangkan asas al-taradin menyatakan bahwa setiap bentuk muamalat antar individu dan antar pihak harus berdasarkan kerelaan masing-masing. Kerelaan ini dapat berarti kerelaan melakukan suatu bentuk muamalat maupun kerelaan dalam menerima dan atau menyerahkan harta yang dijadikan obyek perikatan. ${ }^{7}$

Murabahah yang dipraktikkan di bank syariah adalah akad jual-beli antara bank selaku penyedia barang dengan nasabah yang memesan untuk membeli barang. Dari transaksi tersebut, bank Islam/syariah mendapatkan keuntungan jual-beli yang disepakati bersama di awal kontrak, dan pembayarannya dapat dilakukan secara kredit atau cicilan. ${ }^{8}$ Istilah ini digunakan untuk mengacu pada suatu kesepakatan yang di dalamnya pembelian barang oleh bank dikehendaki konsumennya yang membutuhkan barang tersebut dan kemudian menjual barang itu kepada konsumen dengan harga yang disepakati dengan memberi keuntungan tertentu kepada bank. Pembayaran dilakukan oleh konsumen dalam kurun waktu yang ditentukan dengan cara kredit atau tunai.

Dengan melihat proses dan tujuannya, transaksi Murabahah telah dianggap sebagai transaski yang dibolehkan karena ia mendatangkan manfaat dan keuntungan kepada pihak-pihak yang terlibat (asas tabadu al-manafi). Selain itu, transaksi Murababah dilaksanakan atas dasar suka sama suka bagi pihak-pihak yang terkait (asas al-taradin). Akan tetapi, di sinilah mulai timbul perdebatan, para pengkritik pembiayaan Murabahah melihat adanya kesamaan antara praktik bunga dengan pembiayaan Murabahah di perbankan syari'ah. Kesamaan-kesamaan antara praktik bunga dan praktik pembiyaan Murabahah, menurut para pengkritik, antara lain: adanya perolehan keuntungan yang pasti yang bersifat fixed dan predetermined dalam transaksi Murababah, tidak adanya batasan maksimal laba, adanya penghargaan terhadap unsur waktu (mirip dengan konsep time value of money), keuntungan yang diambil tanpa diikuti dengan pengambilan risiko, kontrak jual-beli dalam Murabahah hanya formalitas belaka; pada dasarnya hubungan antara bank dan

\footnotetext{
${ }^{7}$ Juhaya S. Praja, Filsafat Hukum Islam, (Bandung: LPPM-UIB, 1995), h. 113-114.

${ }_{8}$ Arrison Hendry, Perbankan Syariab: Perspektif Praktisi, (Jakarta: Muamalah Institute, 1990), h. 43.
} 
nasabah sebagai kreditur-debitur dalam transaksi Murabahah adalah sama seperti hubungan antara bank dan nasabah dalam perbankan konvensional; dan lain sebagainya. ${ }^{9}$

Oleh karena itu, dengan melihat teori-teori yang mendukung dan mengkritik pembiayaan Murabahah di bank syariah dan praktik bunga di bank konvensional inilah perlu dilakukan pengkajian tentang sahnya Murabahah di perbankan syariah. Dari sini akan diungkap apa yang menjadi alasan-alasan, dasar logika serta pertimbangan hukum dan metode seperti apa yang dikembangkan oleh para pendukung Murabahah, misalnya fatwa Dewan Syari'ah Nasional Majelis Ulama Indonesia (DSN-MUI) dalam merumuskan fatwa tentang Murabahah. Dari sini akan didapatkan informasi apakah dalam fatwa tersebut, dan pendapat-pendapat sejenis, telah mengakomodasi semua hal yang terkait dengan Murabahah, termasuk pertimbangan terhadap aspek-aspek yang dikritik oleh para pengkritik, atau belum. Jika memang sudah mengakomodasi semua aspek, akan dicari sebab mengapa masih ada kritik yang menyatakan bahwa pembiayaan murabahah tidak memiliki perbedaan mendasar dengan praktik bunga.

\section{Anomali Pembiayaan Murabahah di Perbankan Syari'ah}

Tinjauan tentang produk Murabahah telah banyak dilakukan oleh para ahli, baik dari kalangan ulama, praktisi maupun akademisi dan para pemerhati ekonomi Islam yang ikut memberikan sumbangan pemikiran yang sangat berharga. Berkaitan dengan hal ini, terdapat beberapa penelitian tentang tema seputar Murabahah.

Abdullah Saeed, dalam bukunya yang berjudul "Islamic Banking and Interest: A Study of Probibition of Riba and its Contemporary Interpretation", dalam bab tersendiri memberikan kritik tajam terhadap praktik pembiayaan Murabahah di perbankan Islam. Ia secara konprehensif menelaah unsur-unsur Murabahah di perbankan Islam yang dianggapnya "bermasalah" dari sudut pandang syariah. Saeed menyimpulkan bahwa praktik pembiayaan Murabahab di perbankan syariah adalah tidak lebih dari upaya untuk melakukan riba terselubung, yang ia istilahkan sebagai transaksi "mirip bunga", karenanya ia tidak berbeda dengan praktik bunga di bank konvensional. Meskipun demikian, ternyata transaksi "mirip bunga" atau Murabahab ini dibolehkan dan bahkan berkembang jauh melebihi transaksi Murabahah maupun Musyarakah yang sebenarnya merupakan produk utama yang membedakan bank Islam dengan perbankan konvensional. Oleh karena itulah, dalam catatan penutupnya, ia mempertanyakan bahwa jika fiqh bisa mengizinkan pembiayaan "mirip bunga" atau Murabahah seperti yang dipraktikkan dalam perbankan Islam selama ini, maka adakah pijakan moral untuk tidak mengizinkan bunga tetap pada utang-piutang

\footnotetext{
${ }^{9}$ Lihat Abdullah Saeed, Islamic and..., h. 118-148.
} 
dan dana-dana pinjaman seperti yang dipraktikkan di bank konvensional. ${ }^{10}$ Pandangan sebagaimana yang diungkap Saeed ini tentu saja dapat dijadikan pembanding dalam menganalisa pendapat para ahli yang mendukung Murabahah, tak terkecuali Fatwa DSN-MUI No. 04/DSNMUI/IV/2000 tentang Murabahab di perbankan syariah.

Alasan utama mengapa Abdullah Saeed mengkritik praktik pembiayaan Murabahah, yaitu karena ada kesenjangan antara teori dan praktik dan dianggapnya sebagai bentuk bunga terselubung. Hal-hal yang dikritik Saeed dalam praktik Murabahah sebagai berikut: harga jual Murababah lebih tinggi dari bunga tetap; adanya nilai waktu uang (time value of money) dalam Murababah; tidak adanya batasan maksimal laba yang boleh diambil dalam transaksi Murabahab; dan kontrak jual beli dalam Murabahah hanya formalitas belaka. ${ }^{11}$ Kritik-kritik ini memiliki implikasi cukup signifikan sehingga menimbulkan suatu paradigma bahwa bank Islam tidak berbeda dengan bank konvensional.

Memang harus diakui bahwa pembiayaan Murabahah dalam wacana fiqh dan perbankan syariah telah mengalami banyak perbedaan serta pergeseran wacana, seperti praktik Murabahah dalam literatur-literatur fiqh yang dipahami sebagai penjualan dengan mengambil suatu keuntungan tertentu dengan praktiknya di perbankan syariah dewasa ini. ${ }^{12}$ Perkembangan pemahaman dan praktik yang dipakai dalam transaksi Murabahah di perbankan syariah sekarang ini telah jauh berkembang, dimana perhitungan sistematis dalam menentukan harga jual serta mark-up yang diinginkan telah demikian dipatenkan. Misalnya saja, Syamsul Anwar dalam penelitiannya mencoba melihat operasional perbankan syari'ah dan produk-produknya di BPRS Bangun Drajat Warga Banguntapan Bantul Yogyakarta. Dengan pendekatan normatif-sosialis ia lebih menekankan bagaimana kesesuaian antara idealitas produk yang telah diterapkan dengan pelaksanaan di lapangan. Upaya-upaya yang dilakukan adalah membandingkan antara praktik dan pola kerja produk di lapangan dengan konsep Islamiyah. ${ }^{13}$ Sementara itu, dikatakan juga bahwa transaksi Murabahah diperbolehkan dalam Islam karena transaksi tersebut memberikan keuntungan dan manfaat bersama bagi pihak-pihak yang terlibat. ${ }^{14}$ Secara teoritis, menurut Syamsul Anwar karena pada prinsipnya produk bai' bi tsaman ajil merupakan pengembangan dari

\section{Murabahah.}

\footnotetext{
${ }^{10}$ Ibid.

11 Syaparuddin "Kritik-kritik.., 2007.

12 Qi Mangku Bahjatullah, "Pembiayaan Murabahah dalam Wacana Fiqih dan Perbankan Syari'ah”. Tesis pada Pascasarjana UIN Sunan Kalijaga Yogyakarta, 2007, 86.

${ }^{13}$ Syamsul Anwar, "Permasalahan Produk Bank Syari'ah (Kajian tentang Bai' Muajjal)", Laporan Penelitian Kelompok PPTA, (tidak diterbitkan) pada IAIN Sunan Kalijaga, Yogyakarta, 2000. 42.

${ }_{14}$ Anita Rachmawaty, "Kontroversi Status Keabsahan Murabahah dalam Perbankan Syari'ah (Telaah atas Penerapan Produk di BMI Semarang). Tesis pada Pascasarjana IAIN Sunan Kalijaga Yogyakarata, 2000, 66.
} 
Secara sepintas perbedaan antara sistem bunga dan Murabahah adalah, bahwa keuntungan yang diperoleh oleh bank konvensional yaitu dengan prosentase tertentu, sedangkan mark-up Murabahah merupakan keuntungan yang diambil oleh bank Islam yaitu dengan kesepakatankesepakatan yang telah ditetapkan. Dengan pemahaman seperti ini dapat dijelaskan bahwa bunga dalam perbankan dan mark-up Murabahah pada intinya sama-sama menjadi instrumen bagi bank (termasuk bank Islam) untuk memperoleh keuntungan. Perbedaannya adalah kalau bunga bank dapat diperoleh dengan prosentase tertentu yang telah ditetapkan secara nasional dalam produk pinjaman, sedangkan dalam mark-up Murabahah dapat diperoleh secara bebas oleh bank Islam dari penjualan. Karena itu, mark-up dalam Murabahah adalah sama dengan bunga bank, bahkan lebih memungkinkan mendapatkan keuntungan lebih banyak dari pada bank konvensional. ${ }^{15}$

Pandangan pemikiran yang agak berbeda ditulis oleh Ahmad Dimyati dengan judul "Konsep Keuangan Islam: Studi Pemikiran al-Ghazali dalam Kitab Ibya 'Ulum al-Din.' Dalam mengkaji pemikiran keuangan al-Ghazali dalam kitab Ihya 'Ulum al-Din, yang kemudian direkonstruksi menjadi sebuah konsep keuangan baru membedakan antara konsep time value of money dan bai' muaijal (nama lain Murabahah). Menurutnya, memang jika dilihat secara sekilas tidak ditemukan perbedaan antara keduanya, time value of money dan bai' muajjal (Murabahah), tapi sebenarnya terdapat perbedaan yang mendasar antara keduanya, yaitu: (1) Akad bai' muajjal disandarkan pada objek berupa sektor riil, yaitu melalui transaksi jual-beli barang nyata yang dapat menimbulkan nilai tambah ekonomis (economic value added). Sedangkan dalam konsep time value of money nilai tambah tersebut dapat lahir dari uang itu sendiri, misalkan dalam pinjam-meminjam dengan menerapkan bunga. (2) Tertahannya hak si penjual yang telah melaksanakan kewajibannya dengan menyerahkan barang atau jasa, sehingga ia tidak dapat melaksanakan kewajiban kepada pihak lain. ${ }^{16}$

Dengan paparan di atas, maka dapat dilihat bahwa secara umum tinjauan yang ada mengungkapkan pembicaraan hangat tentang permasalahan praktik pembiayaan murabahab di perbankan syariah, dimana ia dianggap mirip dengan sistem pembiayaan bunga tetap di bankbank konvensional, tetapi ternyata ia tetap dibolehkan di dalam Islam. Hal inilah kemudian yang menimbulkan kontroversi sehingga menyita perhatian para praktisi dan akademisi serta para ulama.

\footnotetext{
15 Akhmad Mulyadi, "Pemikiran Ekonomi Islam: Kajian Metodologis atas Konsep Bunga Bank Fazlur Rahman dan Nejatullah Siddiq.”Tesis pada Pascasarjana IAIN Sunan Kalijaga Yogyakarta, 2001, 12.

16 Ahmad Dimyati, "Konsep Keuangan Islam: Studi Pemikiran al-Ghazali dalam Kitab Ihya 'Ulum al-Din”. Tesis pada Pascasarjana IAIN Sunan Kalijaga Yogyakarta, 2002.
} 


\section{Analisis terhadap Pro-Kontra Pembiayaan Murabahah di Perbankan}

Sebagaimana yang telah diuraiakan di awal, kelompok yang memandang bahwa transaksi Murabahah di perbankan Islam tidak berbeda dengan praktik bunga di bank konvensional. Abdullah Saeed misalnya, mengkritik para teoritisi dan pendukung perbankan Islam yang berargumen bahwa perbankan Islam harus didasarkan pada profit and loss sharing (PLS), bukan berdasarkan bunga. Namun, dalam praktiknya, bank-bank Islam sejak awal telah menemukan bahwa perbankan berdasarkan PLS adalah sulit untuk diterapkan karena penuh risiko dan tidak pasti. ${ }^{17}$ Problem-problem praktis yang terkait dengan pembiayaan ini telah mengakibatkan penurunan bertahap penggunaannya dalam perbankan Islam, dan mengakibatkan peningkatan yang terus-menerus penggunaan mekanisme-mekanisme pembiayaan 'mirip bunga' yang disebut 'Murabahah'. ${ }^{18}$ Saeed dalam kritiknya mengatakan: bahwa harga kredit dalam transaksi Murabahah lebih tinggi dari bunga tetap bank; adanya nilai waktu uang yang membenarkan pengambilan bunga; tidak adanya batasan maksimal pengambilan keuntungan; keuntungan yang diambil tanpa diikuti dengan pengambilan risiko; kontrak jual-beli dalam Murabahah hanya formalitas belaka; hubungan antara bank dan nasabah sebagai kreditur-debitur dalam transaksi murabahah adalah sama seperti hubungan antara bank dan nasabah dalam perbankan konvensional; dan lain sebagainya. ${ }^{19}$

Dengan adanya kritik-kritik seperti itu menunjukkan bahwa praktik pembiayaan Murabahah di perbankan Islam masih dianggap belum memenuhi kriteria halal oleh sebagian ulama. Ada sebagian ulama yang berpendapat bahwa Murabahab bukanlah jual-beli melainkan $b\{$ illah untuk mengambil riba, ada yang menganggapnya sebagai bai' al-inah yang diharamkan Islam, ada yang menganggapnya sebagai bai' al-ma'dum, dan ada juga yang berpandangan bahwa Murabahah dalam perbankan syari'ah sebagai bai' atani fi bi'ah. ${ }^{20}$ Bahkan, ada pula yang berpendapat supaya Murabahah dihapus dari daftar produk yang diperbolehkan di bank syari'ah.

Menariknya, meskipun kritik-kritik semacam itu gencar dilontarkan, namun produk Murabahah pada hampir seluruh perbankan Islam di dunia justru semakin menjadi primadona. Di Indonesia sendiri, produk Murabahah bahkan "merajai" seluruh pembiayaan yang dipraktikkan di perbankan syariah nasional, mengalahkan produk-produk andalan Murababah dan Musyarakah. Untuk kasus Indonesia sendiri, para alim-ulama Indonesia, dalam hal ini Majelis Ulama Indonesia (MUI) misalnya, mengambil sikap yang berbeda dengan pendapat yang menolak praktik

\footnotetext{
17 Abdullah Saeed, Islamic Banking.., 125.

18 Ibid. Lihat juga, Syaparuddin, Kritik-kritik.., 2007.

19 Ibid., h. 118-148.

20 Anita Rahmawaty, "Kontroversi Status Keabsahan Murabahah pada Perbankan Syari'ah (Studi Kasus pada BMI Cabang Semarang)". Tesis pada Pascasarjana UIN Sunan Kalijaga, Yogyakarta, 2000.
} 
Murabahah diterapkan di perbankan syariah. Jika sebagian ulama menganggap bahwa transaksi Murabahah di perbankan syariah tidak lebih dari transaksi bunga terselubung dan menyarankan supaya dihapus saja dari daftar transaksi yang dibolehkan, maka Majelis Ulama Indonesia (MUI) justru mengeluarkan Fatwa DSN-MUI No. 04/DSN-MUI/IV/2000 tentang Murabahah, yang membolehkan praktik Murabahah di perbankan syariah. ${ }^{21}$

Al-Qur'an, bagaimanapun juga, memang tidak pernah secara langsung membicarakan tentang Murabahah, meski di sana ada sejumlah acuan tentang jual-beli, laba, rugi, dan perdagangan. Demikian pula tampaknya tidak ada hadis yang memiliki rujukan langsung kepada Murabahah. Para ulama generasi awal, semisal Imam Malik dan Imam Syafi'i yang secara khusus mengatakan bahwa jual-beli Murabahah adalah halal, tidak memperkuat pendapat mereka dengan satu hadis pun. Al-Kaff, seorang kritikus Murabahah kontemporer, menyimpulkan bahwa Murabahah adalah "salah satu jenis jual-beli yang tidak dikenal pada zaman Nabi saw. atau para sahabatnya".22 Menurutnya, para tokoh ulama mulai menyatakan pendapat mereka tentang Murabahah pada seperempat pertama abad kedua Hijriyah, atau bahkan lebih akhir lagi. ${ }^{23}$

Mengingat tidak adanya rujukan baik di dalam Al-Qur'an maupun hadis sahih yang diterima umum, para fuqaha harus membenarkan Murabahab dengan dasar yang lain. Imam Malik misalnya membenarkan keabsahannya dengan merujuk kepada praktik penduduk Madinah: "Ada kesepakatan pendapat di sini (Madinah) tentang keabsahan seseorang yang membelikan pakaian di kota, dan kemudian ia membawanya ke kota lain untuk menjualnya lagi dengan suatu keuntungan yang disepakati". ${ }^{24}$ Majelis Ulama Indonesia (MUI) sendiri ketika membolehkan Murabahah menggunakan kaidah fiqh: "Pada dasarnya, semua bentuk muamalah boleh dilakukan kecuali ada dalil yang mengharamkan." 25 Akan tetapi, mengingat arti sebuah fatwa yang sudah barang pasti tidaklah mutlak kebenarannya, tentu fatwa tentang kebolehan Murabahab yang dikeluarkan oleh Dewan Syariah Nasional Majelis Ulama Indonesia (MUI) itu dapat dikritisi secara ilmiah. Menimbang berbagai kritikan cerdas dan membangun yang dilontarkan oleh sebagian ulama terhadap praktik Murabahah di perbankan syariah yang selama ini dianggap tidak lebih sebagai "kedok" untuk mengambil riba, maka penelitian untuk mengungkap mengapa MUI (juga pendapat-pendapat lain yang sealiran), misalnya, membolehkan Murabahah, dasar-dasar logika dan pertimbangan seperti apa yang dipakai, serta metode apa yang digunakan amat perlu

\footnotetext{
21 Lihat Fatwa DSN-MUI No. 04/DSN-MUI/IV/2000 tentang Murabahah, dalam Abdul Ghofur Anshori, Payung Hukum Perbankan Syariah: UU Bidang Perbankan, Fatwa DSN-MUI dan Peraturan Bank Indonesia (Yogyakarta: UII Press, 2007 ), h. 82.

22 Abdullah Saeed, Islamic and, h. 119. Bandingkan dengan Syed H.A.R. Al-Kaff, Does Islam Assign..., h.8.

23 Ibid.

24 Ibid., Bandingkan dengan Al-Kaff, Does Islam Assign..., h. 5-6.

25 Fatwa DSN-MUI No. 04/DSN-MUI/IV/2000 tentang Murabahah, dalam Abdul Ghofur Anshori, Payung Hukum Perbankan Syari'ab: UU Bidang Perbankan, Fatwa DSN-MUI dan Peraturan Bank Indonesia (Yogyakarta: UII Press, 2007 ), h. 82.
} 
dilakukan. Hal ini penting dan menjadi sebuah keniscayaan untuk dilakukan dalam rangka memberikan jawaban atas kritik-kritik yang disampaikan, bahkan bila perlu rekonstruksi atas fatwa dan pendapat-pendapat serupa harus dilakukan jika memang ternyata terdapat temuantemuan baru (dari kritik-kritik para ulama) yang mengindikasikan ketidakbolehan Murabahah.

Selain itu, mengingat saat ini transaksi Murabahab bahkan telah begitu dominan melebihi transaksi bagi hasil Murabahah atau Musyarakah yang seharusnya menjadi produk unggulan dan menjadi ciri khas perbankan Islam, maka pembuktian secara ilmiah bahwa transaksi Murabahah merupakan transaksi yang sama syariahnya dengan transaksi lainnya yang berprinsip bagi hasil, Murababah dan Musyarakah, mutlak diperlukan. Jika tidak, maka opini masyarakat saat ini yang mengatakan bahwa bank syariah adalah tidak lebih baik atau bahkan sama saja dengan bank konvensional akan terus berlanjut dan semakin menimbulkan keraguan terhadap ke-syariah-an bank-bank yang dilabeli "Islam/syari'ah". ${ }^{26}$

\section{Perspektif Syari'ah terhadap Metodologi Pengembangan dan Peningkatan Produk Murabahah di Perbankan Syari’ah}

Syari'ah merupakan aturan hukum yang diwahyukan. Ini dimulai dari Al-Qur'an dan Sunnah yang telah dikonstitusikan sebagai sumber hukum Islam yang utama. Syari'ah, sebagai suatu blueprint wahyu yang ditahbiskan bagi pedoman tingkah laku manusia, merupakan sebuah sistem yang meliputi dan mencakup semua aspek kehidupan manusia. Segala bidang; politik, ekonomi dan lain sebagainya telah pula diatur di dalamnya. Oleh karena itu, syari'ah, oleh sarjana Barat digambarkan sebagai "lambang pemikiran Islam, yang merupakan perwujudan dari Islam sebagai pedoman hidup, hakikat dan inti Islam itu sendiri". ${ }^{27}$

Dalam hal ini, penting dicatat bahwa hukum Islam bukanlah sesuatu yang sudah jadi apa adanya. Hukum Islam membutuhkan keterlibatan manusia untuk menafsirkan sumber yang telah diberikan oleh Allah swt. Syari'ah diberikan sebagai sumber hukum untuk dijadikan subyek material bagi fuqaha untuk memahami, menafsirkan dan mengembangkan penerapannya lebih lanjut. Karenanya, pembaruan hukum Islam adalah dasar bagi pengembangan itu sendiri. Secara umum, sumber merupakan tempat dan dasar dari setiap aturan atau alasan hukum diambil. Dalam hal hukum Islam, maka Al-Qur’an dan Sunnah merupakan sumber utama. Keduanya juga

\footnotetext{
26 Opini "miring" yang berkembang di tengah-tengah masyarakat saat ini terkait dengan begitu dominannya transaksi murbahah yang jauh melebihi produk unggulan musyarakah dan mudharabah antar lain dapat disebutkan: Bank syari'ah hanya sekedar "ganti baju"; bank syari'ah bukanlah bank, tapi ia lebih mirip dengan toko atau pasar; Di Indonesia, misalnya, BMI (Bank Muamalat Indonesia) diplesetkan menjdi "Bank Murabahah Indonesia”; BSM (Bank Syari'ah Mandiri) menjadi "Bank Syari'ah Murabahah", dan lain sebagainya. Tentu tanggapan-tanggapan masyarakat semacam itu harus disikapi secara tepat dengan segera membenahi segala kekurangan yang ada yang menjadi sorotan masayarakat. Daam hal inilah kritik-kritik yang bersifat konstruktif amat perlu dipertimbangkan, yang pada akhirnya akan sangat membantu untuk semakin berusaha untuk mewujudkan system perbankan yang benar-benar "syari'ah" dan menghilangkan citra negatif perbankan syari'ah yang ada selama ini.

${ }^{27}$ Joseph Schacht, An Introduction to Islamic Law, (Oxford: Clarendon Press, 1964), h. 1.
} 
bersifat tekstual. Keduanya merupakan teks suci karena keduanya bersumber dari wahyu. Karena alasan inilah, secara historis hukum Islam dikembangkan melalui pendekatan tekstual, dimana seorang fuqaha tidak dibimbing oleh intuisi, tapi oleh teks yang jelas dari al-Qur'an dan Sunnah. Dalam bahasa yang tegas, keduanya bukanlah hukum hasil penafsiran, tapi keduanya adalah sumber hukum itu sendiri. Hukum yang telah tersusun secara rapi dalam subyek-subyek tertentu merupakan produk jadi sebagai hasil interpretasi fuqaha, ia berdiri di akhir, bukan permulaan dari proses penafsiran. ${ }^{28}$

Proses penafsiran ini kemudian dikenal dengan Ijtihad. Pelaku ijtihad adalah fuqaha yang berusaha keras untuk memperoleh atau memformulasikan suatu aturan hukum yang diambil dari dalil-dalilnya yang terperinci dalam sumber-sumber yang ada. Produk jadi dari proses ijtihad ini disebut dengan fiqh, hukum positif Islam, yang berbeda dari syari'ah. Syari'ah adalah hukum yang bersumber dari wahyu, sedangkan fiqh merupakan hasil pemahaman manusia terhadap syari'ah. ${ }^{29}$ Kamal Faruki secara tepat menjelaskan bahwa "perbedaan syari'ah dan fiqh adalah yang pertama merupakan hukum yang didasarkan atas ketetapan wahyu itu sendiri, sedangkan fiqh adalah hasil interpretasi terhadap wahyu itu". Fiqh adalah warisan hukum Islam yang mencakup hampir semua area hukum yang terkait dengan "Islam sebagai pegangan hidup", 30 termasuk di dalamnya adalah kontrak keuangan dan produk perbankan.

Meskipun fiqh didasarkan pada kemampuan berijtihad, yang merupakan karakter manusia, fuqaha tidak bebas begitu saja dalam berusaha untuk berijtihad dalam lapangan fiqh ini. Pendapat fuqaha dalam hal ini tetaplah sebuah penafsiran. Dengan kata lain, validitas suatu pendapat dalam hukum Islam disandarkan pada nilai epistemologi penafsiran yang telah ditetapkan. Jadi, kita bisa menyimpulkan bahwa hukum Islam selalu didasarkan pada konsep ilmiah dan tekstual, bukan didasarkan pada intuisi belaka. Ini bisa dilihat secara jelas dalam tulisan-tulisan cendekiawan muslim seperti al-Syafi'i, Ibn Rushd dan al-Ghazali. Para cendekiawan ini menggunakan landasan epistemologi yang kuat dalam menyampaikan argumentasi hukumnya.

Perbincangan lebih lanjut amat krusial dilakukan untuk memahami tidak hanya pengalaman para juris Muslim atau fuqaha dalam menghadirkan beberapa perbedaan pandangan dan pendirian, tapi juga, lebih penting lagi, untuk mampu menciptakan kreatifitas baru di masa depan dalam bidang hukum Islam. Fiqh, sekalipun merupakan karya penafsiran manusia terhadap hukum Allah (syari'ah), kemudian para fuqaha dan cendekiawan muslim kontemporer yang

\footnotetext{
${ }_{28}$ Hasbi As-Shiddiqi, Falsafah Hukum Islam, cet. IV, (Jakarta: Bulan Bintang, 1993), hlm. 21. Baca juga, Fathurrahman Djamil, Filsafat Hukum Islam, cet. I, (Jakarta: Logos Wacana Ilmu, 1997), h.7.

29 Ibid.

30 Saifudin al-Amidi, al-Ihka $>m$ fi Us\} $u>l$ al-Abka $>m$, (Kairo: Muassasah al-Halabi, 1967), I:8.
} 
dibimbing oleh teori-teori penafsiran terhadap dua sumber al-Qur'an dan Sunnah dan memandang secara objektif terhadap syari'ah, akan mampu melanjutkan pengalaman dan pendekatan yang lebih baik daripada para juris muslim masa lalu. Sebagaimana fuqaha masa lalu menjawab secara baik tantangan permasalahan pada zamannya, maka demikian juga yang dilakukan oleh para fuqaha kontemporer. ${ }^{31}$ Fatwa Ibn Taymiyyah yang membolehkan menyewa kebun buah-buahan patut dijadikan pertimbangan untuk mengetahui bagaimana suatu instrument baru bisa diperkenalkan dan bagaimana instrumen yang ada dapat dikembangkan dan dimodifikasi sedemikian rupa lebih lanjut.

Untuk itu, penting untuk mengetahui prinsip dasar yang secara integral melekat pada hukum Islam sebelum melihat sebuah fatwa. Karena prinsip inilah yang tidak akan berubah, bukan fatwa itu sendiri. Prinsip inilah yang dipakai dalam mengembangkan instrumen yang dianggap memungkinkan dalam fiqh mu'amalah untuk menghadirkan sesuatu yang baru dan tak pernah ada sebelumnya. Prinsip pertama dalam fiqh mu'amalah adalah al-ashlu fi al-ashyi'a alibahah, hatta yarid al-man (asal hukum segala transaksi adalah boleh selama tidak ditemukan dalil yang berlawanan). Prinsip ini tidak berlaku dalam lapangan ibadah. Karena itu, dalam hal perdagangan, perbankan, keuangan, asuransi, pasar saham dan sebagainya, orang dapat berasumsi bahwa semua itu dibolehkan selama tidak ditemukan dalil yang melarangnya. Pada praktiknya, suatu produk baru dengan fitur yang baru dapat pula dikembangkan. Jika suatu saat ditemukan dalam suatu produk terdapat satu atau lebih yang tidak sesuai dengan syariah, maka status hukumnya dapat berubah, dari boleh menjadi dilarang. Jika elemen atau fitur tersebut tidak dimodifikasi, dengan satu alasan dan lain hal, maka untuk memenuhi tuntutan syari'ah, produk tersebut kemudian dilarang dan harus dihindari. ${ }^{32}$

Prinsip lain yang sama pentingnya dalam prinsip mu'amalah adalah al-aslu fi al-mu'amalah alqiyas wa al-ta'lil (asal hukum suatu mu'amalah adalah didasarkan pada analogi (qiyas) dan rasiosinasi (ta'lili/'illah). Ini juga memberikan ruang yang lebih luas bagi fuqaha dan praktisi untuk mengembangkan apa yang telah disebutkan dalam al-Qur'an dan Sunnah, bahkan ijma (konsensus ulama) terhadap suatu hal yang baru dengan mengaplikasikan 'illah (ratio decidendi) dari hukum asal dan menerapkannnya pada hukum bagiannya dimana keduanya memiliki kesamaan 'illah. Contoh buat yang demikian ini sangat banyak dan beberapa fatwa Ibn Taymiyah mungkin dapat menjelaskan prinsip ini.

\footnotetext{
${ }^{31}$ Fathurrahman Jamil, Filsafat..., hlm. 8. Baca juga Muhammad Abu Zahrah, Us\}u>l al-Fiqh, (Bairut: Dar al-Fikr al-Arabi, 1958), h. 56.

32 Mohd. Daud Bakar, "Shari'ah Approaches to Product Development and Product Enhancement in Islamic Banking and Finance: An Appraisal", dalam Essential Reading in Islamic Finance, Ed. Mohd. Daud Bakar dan Engku Rabiah Adawiah Engku Ali, (Malaysia: CERT Publications, 2008), h.117-119.
} 
Prinsip hukum yang lainnya adalah istihsan (equity), ${ }^{33}$ mashlahah (manfaat dan mudharat bagi masyarakat) dan 'urf (adat kebiasaan). Beberapa teknik ini sangat bermanfaat pada masa lalu dan dapat diteruskan pada masa modern saat ini, bahkan di masa yang akan datang. Hukum Islam misalnya membolehkan bay' al-salam. Kebolehan bay'al-salam didukung oleh ulama Hanifiyyah dengan menggunakan istihsan sebagai titik tolak, dari prinsip asal satu hukum kepada hukum lainnya karena suatu alasan yang dianggap lebih nyata, menarik dan lebih aman bagi masyarakat. Prinsip ini disebut denagan istilah istihsan, dalam bahasa Inggris disebut Equity.

Contoh pelaksanaan istibsan di era modern misalnya pembagian dividen kepada para pemegang saham di bursa saham. Idealnya, selama prinsip investasi dilaksanakan, dividen harus didasarkan pada jumlah nyata yang dibagikan kepada masing-masing pemegang saham atau investor. Akan tetapi, pada praktiknya, tingkat dividen yang diberikan akan mengaplikasikan harga perolehan atau nilai saham daripada prinsip dasar akuntansi investasi syari'ah, seperti mudharabah atau musyarakah, tapi titik tolak ini dibenarkan sebagai cara pembagian dividen yang lebih menarik dan aman untuk semua pihak di bursa saham. Sebaliknya, pembagian dividen yang didasarkan pada kontribusi aktual masing-masing dan tiap-tiap pemegang saham pada jumlah yang berbeda dari nilai fluktuasi pasar dinilai sangat sulit dan rumit, untuk tidak mengatakan tak mungkin.

Demikian juga, banyak transaksi pada masa lalu yang didasarkan pada konsep maslabah. Maslahah, sebagai sebuah prinsip hukum, menurut salah satu mazhab adalah kebaikan, harus baik dan sah secara hukum, dan sebaliknya sesuatu yang sah secara hukum harus pula mendatangkan kebaikan. Salah satu jenis maslahah yang cukup menarik perhatian adalah maslahah mursalab (keuntungan dan kebaikan yang tidak ada teks nass-nya) yang tidak bertentangan dengan sumbersumber tertulis hukum Islam. ${ }^{34}$ Pemakaian prinsip ini adalah ketika suatu persoalan mu'amalah kontemporer tak dicakup secara tekstual dalam Al-Qur'an dan as-Sunnah. Persyaratan transaksi jual-beli harus dicatatkan tak diragukan lagi maslahatnya berdasarkan persyaratan yang mendukung keobjektifan hukum Islam dalam memenuhi hak-hak masing-masing pihak.

Disamping istihsan dan maslahah, adat atau kebiasaan masyarakat ('Urf) juga sangat menarik dan sangat signifikan pemakaiannya dalam transaksi perdagangan. Istilah urf atau adat secara umum diartikan seabagai sesuatu yang oleh masyarakat tertentu dipandang sebagai sesuatu yang lazim untuk dilakukan. Adat menempati tempat yang cukup signifikan dalam hukum Islam, khususnya dalam bidang aktifitas perdagangan, bahkan ada satu pribahasa yang terkenal yang

\footnotetext{
33 Iskandar Usman, Istihsan dan Pembaharuan Hukum Islam, cet. I, (Jakarta: PT.Rajagrafindo Persada, 1994$)$, h. 104.

34 Baca lebih lanjut, Hasbi As-Shiddiqi, Falsafah..., h. 32.
} 
telah disepakati bahwa "sesuatu yang diakui sebagai kebiasaan diantara para saudagar adalah dihormati sebagai sauatu kesepakatan di antara mereka." ${ }^{35}$

\section{Praktik Pengembangan dan Peningkatan Produk}

Pengembangan suatu produk pada dasarnya merupakan suatu percobaan untuk menciptakan suatu produk atau instrumen yang baru untuk memenuhi persyaratan khusus bagi pelanggan, regulator, industri dan lain sebagainya. Dalam kebanyakan kasus, penciptaan suatu produk baru, selain untuk tujuan diversifikasi, adalah untuk memuaskan kebutuhan pelanggan dalam segala hal, seperti kerangka hukum, aturan perpajakan dan lain sebagainya. Oleh karena itu, kita akan menjumpai lembaga keuangan secara terus menerus mengembangkan dan meluncurkan produk baru agar memperoleh keuntungan kompetitif dari biaya industri. Akan tetapi, menurut Mohd. Daud Bakar, di industri perbankan konvensional lebih menekankan pada peningkatan mutu produk daripada pengembangan jumlah produk. Bank konvensional cenderung menambah beberapa fitur bagi produk yang telah ada dan mennyatakannya sebagai produk baru. Mungkin ini benar dalam hal produk baru dan dengan fitur yang baru pula, tapi dasar konsep atau kontrak masih tetap sama, yaitu pinjam-meminjam. Ini tak terjadi pada bisnis perbankan Islam dimana produk baru harus berdasarkan konsep dan kontrak yang benar-benar baru. ${ }^{36}$

Dalam konteks ini, mungkin tepat jika contohkan dengan produk Sell and Lease Back pada sewa guna usaha syari'ah. Produk ini merupakan kombinasi dari dua akad yang kemudian menjadi suatu fasilitas pembiayaan. Produk ini awalnya dalam catatan sejarah tak ditemukan dalam diskursus hukum Islam. Akan tetapi, produk ini didasarkan pada dua kontrak, yaitu akad jual dan sewa yang dibolehkan oleh syari'ah. Dari sisi syari'ah, produk ini telah mendapatkan persetujuan dari beberapa dewan syari'ah untuk beberapa institusi keuangan syari'ah. ${ }^{37}$

Produk ini dianggap membantu pelanggan untuk likuiditas assetnya secara tunai atau nilai yang sebanding. Sale and Lease Back adalah pihak lessee yang sebelumnya telah memiliki barang modal tertentu, menjual barang tersebut kepada lessor. Kemudian antara lessor dan lessee saling melakukan kontrak leasing. Dalam model ini, pihak lessee berkepentingan atas uang tunai (cash) yang akan dimanfaatkan untuk menambah modal usaha atau kepentingan lainnya. Upah sewa akan menjadi pendapatan lessor adan lessor akan memberikan persetujuan kepada nasabah untuk membeli kembali asset yang disewakan setelah periode waktu berakhir. ${ }^{38}$ Ini berbeda dengan sale

\footnotetext{
${ }^{35} \mathrm{Ibid}$.

${ }^{36}$ Mohd. Daud Bakar, "Shari'ah..., h. 131.

${ }^{37}$ Ibid.

${ }^{38}$ Lihat, Monir Barakat and Robert W. Taan, "Islamic Leasing Funds" dalam Sohail Jeffer, Islamic Asset Management: Forming the Future for Shari' a Compliant Investment Strategy,( United Kingdom: Money Book, 2004), h. 152-153.
} 
and buy back yang lebih dikenal dengan bay al-inah yaitu akad sewa kemudian sewa kembali atau al-ijarah. Adanya dua kontrak ini masih menjadi perdebatan diantara para ulama. Akad ini adalah akad jual-beli ketika penjual menjual asetnya kepada pembeli dengan janji untuk dibeli kembali secara pembelian secara tangguh (sale and buy back) dengan pihak yang sama.

Contoh lain dari pengembangan produk adalah musyarakah mutanaqisah (decreasing partnership). Akad ini adalah akad bagi hasil yang merupakan penyertaan modal secara terbatas dari satu mitra usaha kepada mitra usaha yang lain untuk jangka waktu tertentu. Dalam salah satu aplikasinya, akad ini digunakan untuk pembiayaan perumahan dan properti. Dalam hal ini pembiayaan dengan akad musyarakah mutanaqisah merupakan bentuk kerjasama kemitraan ketika bank dan nasabah bersama-sama membeli rumah atau properti. Aset tersebut kemudian disewakan kepada nasabah dengan biaya sewa bulanan. Bagian pendapatan sewa nasabah digunakan sebagai penambahan kepemilikan, sehingga pada waktu tertentu (saat jatuh tempo), rumah atau property tersebut menjadi milik nasabah sepenuhnya.

Sementara itu, menurut Mohd. Dau Bakar lebih lanjut, apa yang dimaksud dengan peningkatan produk di sini adalah menambah nilai lebih pada produk yang telah ada sehingga menjadi lebih bagus dan menarik. Peningkatan produk ini tidak merubah konsep suatu produk tapi secara sederhana menambahkan satu atau beberapa fitur baru untuk suatu tujuan tertentu. ${ }^{39}$ Contohnya amat banyak pada keuangan dan perbankan syari'ah. Salah satunya adalah dalam akad mudharabah. Salah satu resikonya adalah resiko kerugian dari modal yang telah diberikan oleh pemberi dana. Tentu, mudharib (manajer) tidak bisa menjamin suatu keuntungan atau bahkan modal yang dipakai dapat memberi keuntungan atau kerugian. Untuk mengatasi hal ini, maka dilibatkanlah pihak ketiga sebagai jaminan. Diskusi tentang ini telah sering dilakukan dan menghasilkan kesimpulan yang mendukung adanya pihak ketiga sebagai penjamin dalam akad mudharabah. Jika fatwa ini dipakai dan diaplikasikan, maka akan semakin memperkuat dan menambah nilai lebih dalam pembiayaan mudharabab. Demikian juga halnya dalam hal murababah tentang resiko penarikan kembali fasilitas yang jual-belikan karena ketidakmampuan membayar oleh nasabah. Hak menarik kembali adalah ketentuan hukum yang ditetapkan dalam hal nasabah tak mampu membayar, sebagai penjual, berhak menekan nasabah sebagai pembeli, untuk melunasi sisa cicilan. Praktik ini dibolehkan oleh AAOIFI.

Dengan demikian, Mohd. Daud Bakar menyimpulkan bahwa diskursus lebih lanjut tentang pengembangan dan peningkatan produk memberikan dua kesan. ${ }^{40}$ Pertama, suatu produk baru

${ }^{39}$ Mohd. Daud Bakar, "Shari’ah..., h. 131-132.

${ }^{40}$ Ibid. 
kadang-kadang dibuat dengan merujuk akad yang telah ada, tapi akad ini kemudian dikombinasikan atau dikonsolidasikan untuk membentuk suatu instrumen baru yang juga memiliki perspektif baru secara bersamaan. Contohnya adalah musyarakah mutanaqisah yang merupakan kombinasi dua akad yaitu musyarakah dan ijarah. Demikian juga halnya dengan akad sale and lease back, takaful, ijarah muntahiya bi al-tamlik.

Kedua, peningkatan (kualitas) produk telah mengambil bentuk dari akad-akad yang telah ada menjadi perspektif dan struktur yang baru yang disesuaikan dengan lingkungan perbankan. Ini karena akad yang ada, secara hukum, dianggap tidak cocok lagi diterapkan untuk bisnis perbankan kontemporer. Misalnya, pada akad istisna' biasa. Namun akad istisna' sederhana ini tidak cocok lagi dengan struktur perbankan bukanlah dalam posisinya sebagai kontraktor bona fide dan bukan pula sebagai pembeli utama. Karena itu, untuk membuat kontrak ini sesuai dengan lingkungan perbankan kontemporer, maka para ahli dan praktisi memperkenalkan konsep istisna' parallel. Akad istisna' parallel adalah akad antara nasabah sebagai pembeli utama dan bank, dan antara bank dengan kontraktor sebagai kontraktor utama. Aplikasi yang sama juga diterapkan pada produk keuangan dan perbankan syari'ah lainnya seperti akad salam parallel, murabahah, dan lain-lain.

Dari pemaparan panjang tentang perspektif syari'ah terhadap pengembangan dan peningkatan (kualitas) produk di atas, maka sesungguhnya produk-produk perbankan syari'ah, termasuk Murabahah, dapat saja dilakukan pengembangan atau peningkatan (kualitas) produk. Dalam arti produk murabahah yang ada dapat dimodifikasi dan dilakukan penambahanpenambahan seperlunya dalam rangka melakukan penyesuaian supaya tidak bertentangan atau mirip dengan transaksi riba. Dari perspektif syari'ah, tentu saja modifikasi dan pengembangan produk murabahah di perbankan syari'ah lebih penting untuk dilakukan daripada harus menghapus murabahah dari daftar produk bank syari'ah. Dengan demikian, semua kritik atas kelemahan praktik murabahah di perbankan syari'ah dapat dijadikan referensi utama sebagai batu loncatan untuk melakukan pengembangan dan peningkatan kualitas produk murabahah di bank syari'ah supaya tidak lagi dikatakan sebagai transaksi mirip bunga pada bank konvensional.

\section{SIMPULAN}

Sebagai sajian penutup, harus dikatakan bahwa munculnya opini publik serta kritik-kritik tajam yang dialamatkan kepada praktik pembiayaan Murabahah di perbankan syariah yang dianggap tidak memiliki perbedaan secara mendasar dengan sistem bunga yang diterapkan pada bank konvensional bisa jadi disebabkan oleh tiga kemungkinan. 
Pertama, aturan hukum yang menjadi dasar pijakan (payung hukum) bagi pengembangan perbankan syari'ah di Indonesia bisa jadi belum mengakomodasi seluruh bagian-bagian penting yang terkait dengan pelaksanaan praktik pembiayaan Murababah di bank syariah, sehingga bankbank yang beroperasi dengan sistem syariah memiliki celah untuk mengambil keuntungan yang mungkin terjerumus kepada riba. Kedua, aturan hukum yang ada mungkin telah lengkap mengatur semua aspek yang menutup pintu terjadinya riba, namun aturan tersebut belum dipatuhi secara sempurna oleh bank syari'ah. Ketiga, masih kurangnya pengembangan dan peningkatan kualitas produk perbankan syari'ah, termasuk produk pembiayaan murabahah. Dengan demikian, jawaban yang diperlukan atas kritikan yang dialamatkan terhadap pembiayaan murababah di perbankan syari'ah adalah perlunya melakukan pengembangan dan peningkatan kualitas produk pada perbankan syari'ah terutama murabahah. Tidak perlu muncul kekhawatiran untuk melakukan rekayasa dan pembenahan dalam rangka melakukan pengembangan dan peningkatan kualitas produk, sebab pada dasarnya syari'ah membolehkan yang demikian itu.

\section{REFERENSI}

al-Amidi, Saifudin, al-Ihka $a m$ fi $U s\} u>l$ al-Ahka $>m$, Kairo: Muassasah al-Halabi, 1967 I:

Anwar, Syamsul, "Permasalahan Produk Bank Syari'ah (Kajian tentang Bai’ Muajjal)", Laporan Penelitian Kelompok PPTA, IAIN Sunan Kalijaga, Yogyakarta, 2000. Tidak diterbitkan.

As-Shiddiqi, Hasbi, Falsafah Hukum Islam, cet. IV, Jakarta: Bulan Bintang, 1993.

Bahjatullah, Qi Mangku, "Pembiayaan Murabahah dalam Wacana Fiqih dan Perbankan Syari'ah”. Tesis pada Pascasarjana UIN Sunan Kalijaga Yogyakarta, 2007.

Bakar, Mohd. Daud, "Shari'ah Approaches to Product Development and Product Enhancement in Islamic Banking and Finance: An Appraisal", dalam Essential Reading in Islamic Finance, Ed. Mohd. Daud Bakar dan Engku Rabiah Adawiah Engku Ali, Malaysia: CERT Publications, 2008.

Barakat, Monir and Robert W. Taan, "Islamic Leasing Funds" dalam Sohail Jeffer, Islamic Asset Management: Forming the Future for Shari'a Compliant Investment Strategy, United Kingdom: Money Book, 2004.

Dimyati, Ahmad, "Konsep Keuangan Islam: Studi Pemikiran al-Ghazali dalam Kitab Ihya 'Ulum al-Din”. Tesis pada Pascasarjana IAIN Sunan Kalijaga Yogyakarta, 2002.

Djamil, Fathurrahman, Filsafat Hukum Islam, cet. I, Jakarta: Logos Wacana Ilmu, 1997. 
Fatwa DSN-MUI No. 04/DSN-MUI/IV/2000 tentang Murabahah, dalam Abdul Ghofur Anshori, Payung Hukum Perbankan Syariah: UU Bidang Perbankan, Fatwa DSN-MUI dan Peraturan Bank Indonesia, Yogyakarta: UII Press, 2007.

Hendry, Arrison, Perbankan Syari'ab: Perspektif Praktisi, Jakarta: Muamalah Institute, 1990.

Iqbal, Zamir dan Abbas Mirakhor, Pengantar Kenangan Islam: Teori dan Praktek, terj. A.K. Anwar, cet. I, Jakarta: Kencana, 2008.

Usman, Iskandar, Istibsan dan Pembaharuan Hukum Islam, cet. I, Jakarta: PT.Rajagrafindo Persada, 1994.

Zahrah, Muhammad Abu, Us\}u>l al-Fiqh, Bairut: Dar al-Fikr al-Arabi, 1958.

Karim, Adiwarman A., Bank Islam: Analisis Fiqib dan Kenangan, Jakarta: PT. RajaGrafindo Persada, 2004.

Muslihun, "Argumen-arguimen Baru Pro-Kontra Bunga Bank", dalam Istinbath, No. 2, Vol. 1 Januari-Juni 2004.

Mulyadi, Akhmad, "Pemikiran Ekonomi Islam: Kajian Metodologis atas Konsep Bunga Bank Fazlur Rahman dan Nejatullah Siddiq."Tesis pada Pascasarjana IAIN Sunan Kalijaga Yogyakarta, 2001.

Praja, Juhaya S., Filsafat Hukum Islam, Bandung: LPPM-UIB, 1995.

Rachmawaty, Anita, "Kontroversi Status Keabsahan Murabahah dalam Perbankan Syari'ah (Telaah atas Penerapan Produk di BMI Semarang). Tesis pada Pascasarjana IAIN Sunan Kalijaga Yogyakarata, 2000.

Saeed, Abdullah, Islamic Banking and Interest: A Study of Probibition of Riba and Its Contemporary Interpretation, Leiden: E..J. Brill, 1996.

Syed H.A.R. Al-Kaff, Does Islam Assign any Value/Weight to time Factor in Economic and Financial Transactions?,Karachi: Islamic Research Academy, 1986.

Suhirman, Gatot, "Bunga dan Riba dalam Transaksi menurut Syari’ah:Sebuah Ikhtiar Mengurai Akar Perbedaan Pendapat", dalam Alamab: Jurnal Pembaruan Pemikiran Islam, Vol. VI, Januari-Desember 2008.

Syaparuddin, "Kritik-kritik Abdullah Saeed terhadap Praktik Pembiayaan Murabahab", Tesis pada Pascasarjana UIN Sunan Kalijaga, Yogyakarta, 2007. 